\title{
ANALISIS KESALAHAN SISWA PADA KEMAMPUAN KOMUNIKASI MATEMATIS DALAM PEMBELAJARAN YANG MENGGUNAKAN PENDEKATAN SAINTIFIK
}

\author{
Dea Tri Septiani ${ }^{1)}$, Ari Septian ${ }^{2)}$, Erwan Setiawan ${ }^{3)}$ \\ ${ }^{1), 2), 3)}$ Program Studi Pendidikan Matematika, Universitas Suryakancana, Jl. Pasir Gede Raya, \\ Cianjur, Jawa Barat, Indonesia \\ deatriseptiani28@gmail.com ${ }^{1)}$, ariseptian@unsur.ac.id ${ }^{2)}$,erwan@unsur.ac.id ${ }^{3)}$
}

\begin{abstract}
The purpose of this study is to determine the level of mathematical communication ability of students in learning that uses a scientific approach, find out the mistakes that are often made by students and which are the causes of students making mistakes. The subjects in this study were students of class XI MIPA 3 MAN 1 Cianjur. This research method is descriptive qualitative and the instruments used consist of tests of mathematical communication ability and interviews. The results of this study are students' ability in explaining ideas, situations, and mathematical relationships in writing with real objects, pictures, graphics and algebra by $34 \%$. Mathematical communication ability of students in explaining ideas, situations, and mathematical relationships in writing with real objects, pictures, graphics and algebra by $25 \%$. The ability of students' mathematical communication in expressing everyday events in language, mathematical symbols, composing a mathematical model of an event is $30 \%$. Mistakes that are often made by students in this study are concept errors, operating errors, and lack of accuracy. As for what causes students to make mistakes is due to factors of forgetfulness, lack of accuracy, difficulty in learning and less study time at home.
\end{abstract}

Keywords: Error Analysis, Mathematical Communication, Scientific Approach

\begin{abstract}
Abstrak
Tujuan dari penelitian ini adalah mengetahui tingkat kemampuan komunikasi matematis siswa pada pembelajaran yang meggunakan pendekatan saintifik, mengetahui kesalahan yang sering dilakukan oleh siswa dan yang menjadi penyebab siswa melakukan kesalahan. Subjek pada penelitian ini adalah siswa/i kelas XI MIPA 3 MAN 1 Cianjur. Metode penelitian ini adalah deskriptif kualitatif dan instrumen yang digunakan terdiri dari tes kemampuan komunikasi matematis dan wawancara. Hasil dari penelitian ini menunjukkan kemampuan siswa dalam menjelaskan ide, situasi, dan relasi matematis secara tulisan dengan benda nyata, gambar, grafik dan aljabar sebesar 34\%. Kemampuan komunikasi matematis siswa dalam menjelaskan ide, situasi, dan relasi matematis secara tulisan dengan benda nyata, gambar, grafik dan aljabar sebesar $25 \%$. Kemampaun komunikasi matematis siswa dalam menyatakan peristiwa sehari-hari dalam bahasa, simbol matematika, menyusun model matematika suatu peristiwa sebesar $30 \%$. Kesealahan yang sering dilakukan siswa dalam penelitian ini adalah kesalahan konsep, kesalahan operasi, dan kurang teliti. Adapun yang menjadi penyebab siswa melakukan kesalahan adalah karena faktor lupa, kurang teliti, kesulitan dalam belajar dan waktu belajar dirumah yang kurang.
\end{abstract}

Kata Kunci : Analisis Kesalahan, Komunikasi Matematis, Pendekatan Saintifik

Cara Menulis Sitasi: Septiani, D. T., Septian, A., \& Setiawan, E. (2020). Analisis Kesalahan Siswa pada Kemampuan Komunikasi Matematis dalam Pembelajaran yang Menggunakan Pendekatan Saintifik . Jurnal Edukasi dan Sains Matematika (JES-MAT),6 (2), 65-80. 


\section{PENDAHULUAN}

Berdasarkan data dari Programme for International Student Assessment (PISA) tahun 2018, Indonesia menduduki peringkat ke 72 dari 78 dengan rata-rata nilai 379 dan rata-rata skor dunia untuk matematika adalah 489. Hal ini menunjukan bahwa prestasi belajar matematika siswa Indonesia masih sangat rendah (Schleicher, 2018). Dalam tes Programe for International Student Assesment (PISA) ada 4 kemampuan matematika yang dinilai, yaitu kemampuan pemahaman, pemecahan masalah (problem solving), kemampuan penalaran (reasoning) dan kemampuan komunikasi (communication). NCTM pada tahun 2000 menetapkan 5 kemampuan matematis, meliputi: penalaran matematis, representasi matematis, koneksi matematis, komunikasi matematis dan pemecahan masalah matematis (NCTM, 2000). Dari kelima kemampuan tersebut, kemampuan komunikasi matematis merupakan kemampuan yang perlu ditingkatkan karena berdasarkan penelitian yang dilakukan oleh (Wulan, 2016) didapatkan bahwa tingkat kemampuan komunikasi matematis siswa masih tergolong rendah. Siswa masih merasa kesulitan dalam menyelesaikan soal jenis kemampuan komunikasi matematis (Wulandari, 2016).

Kemampuan komunikasi menjadi salah satu aspek yang dinilai. Komunikasi matematis bukanlah kemampuan yang sudah ada, tetapi kemampuan itu perlu dikembangkan dalam pembelajaran (Anggriani \& Septian, 2019). Untuk dapat mengembangkan kemampuan tersebut perlu dikaji apa dan bagaimana kemampuan komunikasi matematis yang dimaksud secara teoritis. (Ramellan, Musdi, \& Armiati, 2012).

Upaya untuk mengembangkan atau meningkatkan kemampuan komunikasi matematis dapat diawali dengan menganalisis penyebab kemampuan tersebut rendah (Nopiyani, Turmudi, \& Prabawanto, 2018). Salah satu yang dapat dilakukan untuk menganalisisnya yaitu melalui analisis kesalahan yang dilakukan siswa dalam mengerjakan soal kemampuan komunikasi matematis. Analisis yang dilakukan peneliti dengan peneliti-peneliti sebelumnya jelas berbeda. Perbedaan dapat dilihat dari deskripsi hasil dan pembahasan yang didapatkan. Melalui analisis kesalahan akan diketahui dimana letak kesalahan siswa dan dapat membantu siswa untuk meningkatkan prestasi belajar. Analisis kesalahan pun dapat membantu guru dalam menerapkan pendekatan, model dan metode belajar yang tepat agar guru dapat menciptakan suasana belajar yang optimal dan tujuan pembelajaran dapat tercapai (Jusniani, 2018).

Kesalahan-kesalahan yang dilakukan oleh siswa dalam menyelesaikan persoalan matematika dapat diperbaiki dan diatasi melalui proses belajar yang optimal, dengan ditunjang oleh sarana dan prasarana yang baik. Proses pembelajaran akan optimal jika komunikasi dan interaksi antara guru dengan siswa berjalan secara intensif. Hal ini dapat terjadi jika guru dapat merancang pendekatan, model, metode pembelajaran yang tepat. (Inayah, Septian, \& Suwarman, 2020).

Pendekatan yang bisa diterapkan dalam upaya untuk mengembangkan 
kemampuan komunikasi matematis adalah pendektan sainitifik. Langkah-langkah dalam pendekatan saintifik ada 5 yaitu mengamati, menanya, mengumpulkan data, mengasosiasi dan mengkomunikasikan (Maskur et al., 2020). Salah satu langkah dalam pendekatan saintifik itu ada kaitannya dalam upaya mengembangkan kemampuan komunikasi matematis, yaitu langkah mengkomunikasikan.

Mengkomunikasikan yaitu kegiatan siswa mendeskripsikan dan menyampaikan hasil temuannya dari kegiatan mengamati, menanya, mengumpulkan dan mengolah data, serta mengasosiasi yang ditujukan kepada orang lain baik secara lisan maupun tulisan dalam bentuk diagram, bagan, gambar, dan sejenisnya dengan bantuan perangkat teknologi sederhana dan atau teknologi informasi dan komunikasi. Hasil belajar dari kegiatan mengomunikasikan adalah siswa dapat memformulasikan dan mempertanggung jawabkan pembuktian hipotesis (Sufairoh, 2016).

Proses pendekatan saintifik lebih menekankan pada kemampuan siswa dan guru hanyalah menjadi fasilitator saat proses pembelajaran berlangsung, serta guru bukan hanya satu-satunya sumber belajar dan siswa lebih banyak mencari tahu sendiri dan bukan diberi tahu oleh guru. Siswa dapat mencari sumber belajar lain seperti buku, jurnal bahkan internet. (Sun, Xie, \&Andreman, 2018).

Beberapa peneliti telah melakukan analisis kemampuan komunikasi matematika pada pembelajaran yang menggunakan pendekatan saintifik diantaranya adalah Mamluatul Mufida (2015), Permata, dkk (2015). Mamluatul Mufida melakukan analisis kemampuan komunikasi matematis pada model PBL dengan pendekatan saintifik berdasarkan gaya belajar siswa kelas VIII. Sedangkan Permata, dkk (2015) menganalisis kemampuan komunikasi matematis siswa kelas VIII SMP pada model pembelajaran TSTS dengan pendekatan scientific.

Penelitian ini berujuan untuk mengetahui tingkat kemampuan komunikasi matematis siswa pada pembelajaran pendekatan saintifik, mengetahui kesalahan dan penyebab siswa melakukan kesalahan.

\section{LANDASAN/KAJIAN TEORI Analisis Kesalahan}

Analisis adalah penyelidikan terhadap suatu peristiwa (karangan, perbuatan, dsb) untuk mengetahui keadaan yang sebenarnya (sebab-musabab, duduk perkaranya, dsb) (KBBI, 2016). Kesalahan merupakan penyimpangan dari hal yang sudah diketahui kebenarannya. Jadi analisis kesalahan adalah penyelidikan terhadap suatu peristiwa penyimpangan yang dilakukan. Analisis kesalahan disini adalah penyelidikan terhadap penyimpangan yang dilakukan siswa dalam menyelesaikan soal matematika tertentu.

Jenis-jenis kesalahan yaitu, kesalahan siswa dalam menyelesaikan soalsoal meliputi kesalahan konsep, kesalahan operasi dan kesalahan ceroboh dengan kesalahan yang paling dominan adalah kesalahan konsep (Kristofora \& Sujadi, 2017). Kesalahan konsep merupakan kesalahan yang dilakukan siswa dalam menafsirkan konsep. Atau salah dalam menggunakan konsep (Kastolan, 1992:6 dalam Sahriah). Kesalahan prosedural adalah kesalahan dalam menyusun langkah langkah yang sistematis dalam menyelesaikan suatu masalah.

Penyebab siswa melakukan kesalahan dalam menyelesaikan soal dapat 
dilihat dari berbagai hal. Adapun klasifikasi kesalahan yang dilakukan oleh siswa, diantaranya:

1. Kesalahan procedural; dalam menggunakan Algoritma (prosedur pekerjaan), contohnya kesalahan melakukan opersi hitung.

2. Kesalahan dalam mengorganisasikan data, contohnya kesalahan menuliskan apa yang diketahui, apa yang ditanyakan dari suatu soal.

3. Kesalahan mengurutkan, mengelompokkan dan menyajikan data.

4. Kesalahan pemanfaatkan simbol, tabel dan grafik yang memuat suatu informasi.

5. Kesalahan melakukan manipulasi secara matematis, sifat-sifat dalam menyelesaikan soal.

6. Kesalahan dalam menarik kesimpulan. Contohnya kesalahan dalam menuliskan kesimpulan dari persoalan yang telah mereka kerjakan.

Penyebab kesalahan siswa meliputi faktor secara internal dan faktor secara eksternal. Faktor Internal diantaranya; faktor kematangan, faktor fisiologis, faktor psikis, kesulitan belajar yang dialami siswa, lupa, kurang teliti dalam menjawab soal. Adapaun faktor ekternal siswa melakukan kesalahan yaitu sebagai berikut; kesalahan informasi dari guru, karakteristik materi, fasilitas belajar, dan lingkungan belajar

\section{Komunikasi Matematis}

Kemampuan komunikasi matematis merupakan kemampuan siswa untuk mengkomunikasiikan ide matematisnya baik secara lisan maupun tulisan sehingga siswa tersebut dapat mengembangkan sendiri pemahaman yang dimilikinya dan dapat membangun pengetahuannya serta siswa juga dapat mengaitkan pengalaman belajarrnya dalam mempelajari konsepkonsep matematika yang sebenarnya (Anggriani \& Septian, 2019). Berdasarkan uraian tersebut maka dapat disimpulkan bahwa Kemampuan Komunikasi matematis merupakan

kemampuan mengkomunikasikan gagasan dengan simbol-simbol, grafik, atau diagram untuk menjelaskan suatu keadaan atau masalah.

Untuk mengukur kemampuan komunikasi matematis diperlukan beberapa indikator. Adapun indikator kemampuan komunikasi matematis menurut Sumarmo dan Hendriana sebagai berikut.

1. Melukiskan atau mempresentasikan benda nyata, gambar, dan diagram dalam bentuk ide atau simbol matematika.

2. Menjelaskan ide, situasi dan relasi matematik, secara lisan dan tulisan dengan menggunakan benda nyata, gambar, grafik dan ekspresi aljabar.

3. Menyatakan peristiwa sehari-hari dalam bahasa, simbol matematika, menyusun model matematika suatu peristiwa. (Hendriana \& Sumarmo, 2017)

\section{Pendekatan Saintifik}

Pendekatan saintifik merupakan proses pembelajaran yang dirancang sedemikian rupa agar peserta didik secara aktif mengonstruk konsep, hokum, prinsip melalui tahapan-tahapan mengamati (untuk mengidentifikasi, menemukan masalah), merumuskan masalah, mengajukan, merumuskan hipotesis, mengumpulkan data dengan berbagai teknik, menganalisis data, menarik kesimpulan dan mengomunikasikan konsep, hokum, prinsip yang “ditemukan" (Sufairoh, 2016). 
Proses pembelajaran yang mengacu pada pendekatan saintifik menurut Kementerian Pendidikan dan Kebudayaan (2016) meliputi lima langkah, yaitu: mengamati, menanya, mengumpulkan data, mengasosiasi, dan mengkomunikasikan.

\section{METODE PENELITIAN}

\section{Jenis Penelitian}

Penelitian ini menggunakan deskriptif kualitatif. Deskriptif kualitatif ini adalah sebuah jenis penelitian yang dalam mendeskripsikan suatu keadaan atau fenomena yang ada pada saat penelitian. Kejadian atau fenomena yang terjadi memang benar-benar sesuatu yang terjadi, tidak dilebih-lebihkan atau dikurangkurangkan.

\section{Waktu dan Tempat Penelitian}

Penelitian dilakukan dari bulan September 2019 hingga Febuari 2020. Dimulai dengan observasi, mengambil data dan wawancara siswa.

Penelitian ini dilakukan di MAN 1 Cianjur yang beralamat di Jl. Pangeran Hidayatullah No. 39 Kode Pos 43211, Kabupaten Xianjur, Jawa Barat, Indonesia.

\section{Target/Subjek Penelitian}

Subjek pada penelitian ini adalah 35 siswa/i kelas XI MIPA 3 MAN 1 Cianjur Tahun Ajaran 2019-2020. Karakteristik siswa pada dasarnya hampir sama (homogen) dengan latar belakang siswa yang berbeda.

\section{Prosedur}

Dalam penelitian ini peneliti melakukan observasi saat melakukan pengenalan lapangan persekolahan di MAN 1 Cianjur. Adapun prosedur yang dilalui adalah meminta izin penelitian terhadap pihak sekolah. Kemudian setelah mendapatkan izin peneliti mempersiapkan bahan yang dibutuhkan untuk penelitian.
Setelah dilakukan penelitian, peneliti akan menganalisis kesalahan siswa setelah mengerjakan soal kemampuan komunikasi matematis. Analisis data kesalahan siswa dilakukan untuk meningkatkan kemampuan komunikasi matematis dengan mengevaluasi berbagai kesalahan yang dilakukan oleh siswa.

Data, Intrumen, dan Teknik Pengumpulan Data

Data dalam penelitian ada dua, yaitu data primer dan data sekunder. Data primer dalam penelitian ini adalah hasil tes tertulis kemampuan komunikasi matematis dan hasil wawancara siswa. Data sekunder dalam penelitian ini adalah segala bentuk dokumentasi seperti daftar nama siswa dan dokumentasi penelitian.

Intrumen dalam penelitian ini ada tiga, yaitu human instrument, soal tes tertulis, dan wawancara.

Teknik pengumpulan data dilakukan dengan tiga tahap yaitu metode observasi, meode tes tertulis dan metode wawancara. Observasi yang dilakukan dalam penelitian ini adalah observasi partisipasi, karena peneliti bertindak sebagai instrumen utama. Observasi adalah suatu metode atau cara untuk menganalisis dan melakukan pencatatan yang dilakukan secara sistematis, tidak hanya terbatas dari orang, tetapi juga obyek-obyek alam yang lain (Sugiyono, 2010). Tes dilakukan dalam penelitian ini untuk memperoleh data kemampuan komunikasi matematis yang dapat dilihat pada jawaban tes siswa. Instrumen tes dalam penelitian ini adalah tes tertulis dengan bentuk uraian. Wawancara dilakukan agar peneliti dapat mengetahui penyebab kesalahan yang dilakukan oleh siswa.

\section{Teknik Analisis Data}


Analisis data yang dilakukan pada penelitian ini terdiri dari dua bentuk, yaitu analisis jawaban hasil tes dan analisis hasil wawancara dengan uraian sebagai berikut.

Analisis Jawaban Hasil Tes

Tes Analisis jawaban hasil tes dilakukan dengan mengoreksi kesalahankesalahan siswa saat mengerjakan soal tes kemampuan komunikasi matematis. Kesalahan-kesalahan tersebut kemudian dicatat dan dikualifikasikan berdasarkan letak kesalahannya. Kesalahan siswa berdasarkan hasil jawaban pada lembar jawaban yang telah disediakan peneliti kemudian peneliti menghitung persentase indikator setiap bentuk kesalahan.

\section{Analisis Wawancara}

Wawancara dilakukan agar peneliti mengetahui letak kesalahan yang dilakukan oleh siswa. Wawancara dilakukan kepada siswa berdasarkan kategori kelas atas, tengah dan bawah. Dengan perhitungan didapatkan 9 siswa menjadi sampel dalam wawancara. Analisis wawancara dilakukan dengan melihat kembali kesalahankesalahan yang sudah dicatat saat memerikasa jawaban soal tes dan hasil wawancara. Kemudian peneliti akan memverifikasi kesalahan siswa dengan memberikan soal yang sejenis. Agar memperoleh data lebih lanjut peneliti juga akan menggunakan jenis-jenis kesalahan yang dilakukan siswa untuk dijadikan pertanyaan dalam menentukan faktor penyebab terjadinya kesalahan siswa saat mengerjakan soal.

\section{HASIL PENELITIAN DAN PEMBAHASAN \\ Data Hasil Tes}

Proses pembelajaran menggunakan pendekatan saintifik yang mengacu pada Kementerian Pendidikan dan Kebudayaan (2016) meliputi lima langkah, yaitu: mengamati, menanya, mengumpulkan data, mengasosiasi, dan mengkomunikasikan. Komunikasi menjadi fokus utama peneliti dalam menilai kemampuan komunikasi matematis. Berdasarkan hasil analisis yang telah dilakukan peneliti terhadap jawaban siswa dalam mengerjakan soal kemampuan komunikasi matematis didapatkan bahwa kemampuan komunikasi pada tiap indikator tergolong rendah hingga sedang. Kategori kemampuan komunkasi matematis siswa disajikan pada tabel 1 dan besaran persentase disajikan pada tabel 2.

Tabel 1. Kategori Kemampuan Komunikasi Matematis

\begin{tabular}{cc}
\hline Kategori & Kemampuan Komunikasi Matematis \\
\hline Tinggi & $66 \%-100 \%$ \\
\hline Sedang & $34 \%-67 \%$ \\
\hline Rendah & $0-33 \%$ \\
\hline
\end{tabular}

Tabel 2. Presentase Siswa Menjawab Benar tiap Indikator

\begin{tabular}{lc}
\hline \multicolumn{1}{c}{ Indikator } & $\begin{array}{c}\text { Persentase Hasil Tiap } \\
\text { Indikator }\end{array}$ \\
\hline $\begin{array}{l}\text { Menghubungkan benda nyata, gambar atau diagram ke } \\
\text { dalam ide matematika. }\end{array}$ & $34 \%$ \\
\hline Menjelaskan ide, situasi, dan relasi matematis secara & $25 \%$ \\
\hline
\end{tabular}




\begin{tabular}{lc}
\hline \multicolumn{1}{c}{ Indikator } & $\begin{array}{c}\text { Persentase Hasil Tiap } \\
\text { Indikator }\end{array}$ \\
\hline tulisan dengan benda nyata, gambar, grafik dan aljabar & \\
\hline $\begin{array}{l}\text { Menyatakan peristiwa sehari-hari dalam bahasa atau } \\
\text { simbol matematika atau menyusun model matematika } \\
\text { suatu peristiwa }\end{array}$ & $30 \%$ \\
\hline
\end{tabular}

Berdasarkan tabel 2 persentase pada indikator pertama yang diwakili soal nomor 1, 2 dan 4 yaitu melukiskan atau mempresentasikan benda nyata, gambar, dan diagram dalam bentuk ide dan atau simbol matematika adalah 34\%, berdasarkan kategori tingkat kemampuan komunikasi matematis maka pada indikator tersebut adalah sedang. Hanya beberapa siswa yang mampu menghubungkan grafik ke dalam ide matematika walaupun jawaban siswa masih terdapat kesalahan sehingga siswa masih tergolong rendah pada indikator ini.

Apabila pada indikator kedua diwakili nomor soal ke 3 yaitu menjelaskan ide, situasi dan relasi matematik, secara lisan dan tulisan dengan menggunakan benda nyata, gambar, grafik dan ekspresi aljabar termasuk dalam kategori rendah dengan persentase $25 \%$. Berdasarkan hasil jawaban, masih banyak siswa yang menjawab dengan tidak tepat dalam menjelasakan sebuah fungsi yang diketahui disoal kedalam sebuah grafik. Siswa masih merasa kebingungan untuk menjawab pesoalan tersebut.

Pada indikator ketiga diwakili nomor soal ke 5 yaitu menyatakan peristiwa sehari-hari dalam bahasa atau simbol matematika atau menyusun model matematika suatu peristiwa. Termasuk pada kategori rendah dengan persentase $29 \%$. Dalam indikator ini ada beberapa siswa dapat membuat model matematika dari pesoalan yang diketahui disoal, walaupun jawaban siswa masih banyak yang melakukan kesalahan, bahkan ada beberapa siswa yang tidak dapat membuat permodelan matematika.

Adapun beberapa penelitian yang relevan dengan penelitian yang peneliti ambil seperti penelitian yang dilakukan oleh Rindawati (2017), Aminah dan Yuspriyati (2017) dan Permata, dkk (2015). Hasil penelitian yang dilakukan Rindawati (2017) yaitu tingkat kemampuan komunikasi matematis SMP di Kabupaten Tasikmalaya berdasarkan hasil tes dan wawancara tergolong sangat rendah. Hasil penelitian yang dilakukan oleh Aminah dan Yuspriyati (2017) menu jukan bahwa kemampuan komunikasi matematis.

\section{Data Wawancara}

Berdasarkan hasil jawaban siswa Berdasarkan hasil jawaban siswa masih terdapat banyak kesalahan dan ada beberapa kesalahan yang sering dilakukan oleh siswa, seperti:

1. Lupa.

2. Kurang teliti.

3. Kesulitan belajar yang dialami siswa.

4. Waktu untuk belajar di rumah kurang.

\section{Analisis Kesalahan}

Bentuk Kesalahan yang Sering dilakukan Siswa

Berdasarkan hasil jawaban siswa masih terdapat banyak kesalahan dan ada beberapa kesalahan yang sering dilakukan oleh siswa, seperti berikut: 


\section{Kesalahan Konsep}

Berikut salah satu contoh hasil kerja siswa dalam menyelesaikan soal kemampuan matematis dan mengalami kesalahan konsep.

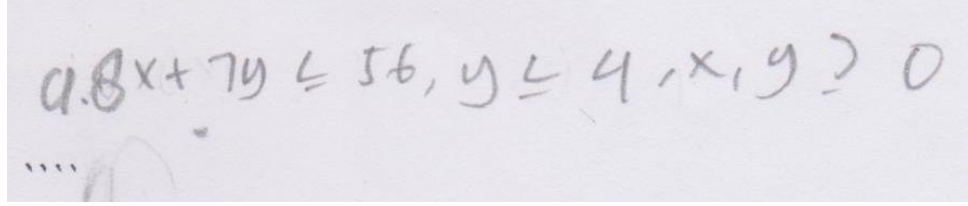

Gambar 1. Kesalahan Konsep

Berdasarkan gambar 1. siswa masih melakukan kesalahan dalam memahami konsep dari grafik disoal. Kesalahan konsep adalah kesalahan yang dilakukan siswa dalam menafsirkan konsep. Konsep yang digunakan haruslah siswa menuliskan titik $\mathrm{x}$ dikalikan dengan sumbu y dan titik y dikalikan dengan sumbu $\mathrm{x}$, tetapi siswa tersebut masih menuliskan dengan persamaan yang keliru. Siswa pun melakukan kesalahan dalam memahami garis $\mathrm{x} \leqslant 4$ karena siswa tersebut menjawabnya dengan persamaan $y \leqslant 4$.

2. Kesalahan prosedural yaitu dalam menggunakan Algoritma

Berikut salah satu contoh hasil kerja siswa dalam menyelesaikan soal kemampuan matematis dan mengalami kesalahan prosedural yaitu dalam menggunakan Algoritma.

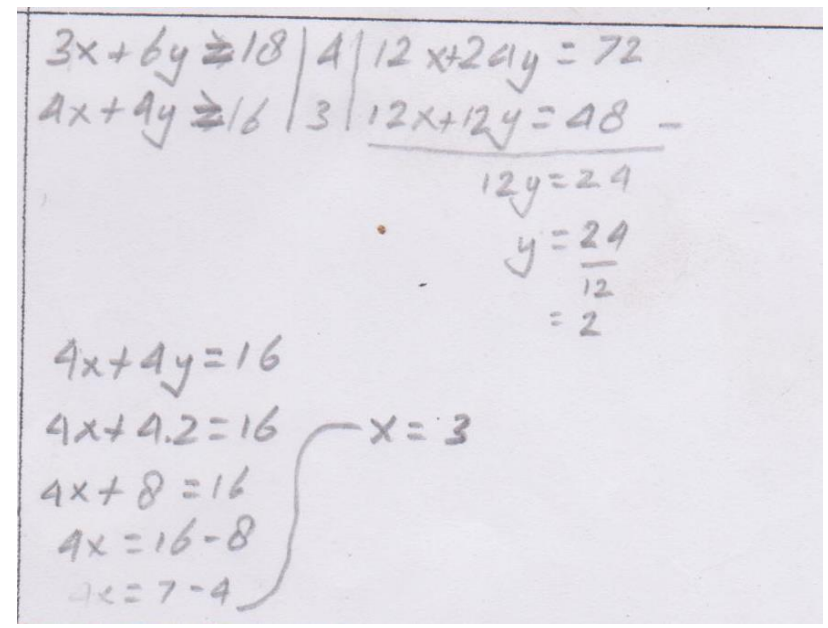

Gambar 2 Kesalahan menggunakan Algoritma

Pada gambar 2 terlihat bahwa siswa masih melakukan kesalahan pada operasi hitung. Siswa melakukan kesalahan saat akan mencari nilai $x$. Ketika siswa menuliskan $4 \mathrm{x}+8=16$, siswa tersebut mengurangi kedua ruas dengan 8 sehingga didapatlah seperti pada gambar 4.2 tetapi saat siswa sudah mengurangi dengan 8 siswa mendapatkan hasil $4 x=7-4$ dan siswa mebuat kesimpulan bahwa nilai $\mathrm{x}$ adalah 3. Terdapat kesalahan pada operasi hitung haruslah kedua ruas dibagi dengan 4 tetapi siswa tersebut mengurangi fungsi tersebut. Ketika siswa diwawancarai mengenai hal tersebut siswa masih bingung membedakan cara mengoperasikan suatu fungsi. 
3. Kurang teliti atau ceroboh

Berikut salah satu contoh hasil kerja siswa dalam menyelesaikan soal kemampuan matematis dan mengalami kesalahan kurang teliti atau ceroboh.

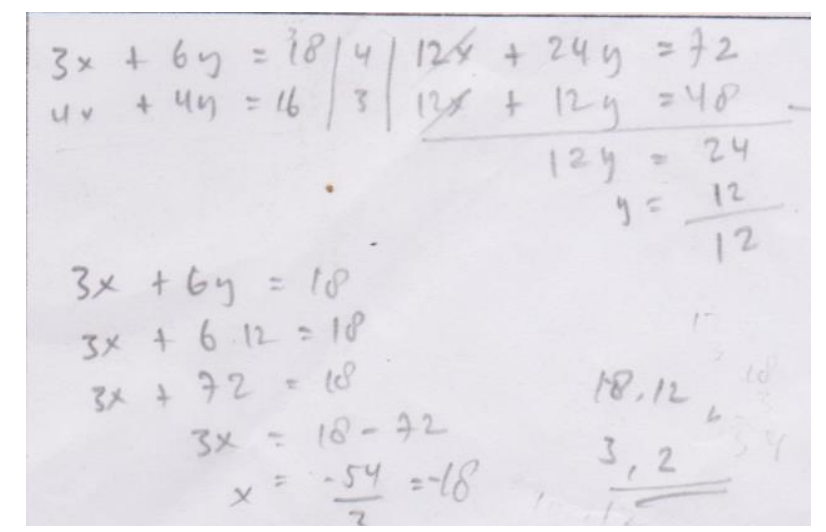

Gambar 3. Kesalahan kurang teliti atau ceroboh

Pada gambar 3 ada kecerobohan yang dilakukan oleh siswa dalam mencari nilai y. Dalam mencari sebuah nilai y siswa tersebut menulis 12 dibagi dengan 12 haruslah siswa tersebut menulis 24 dibagi dengan 12. Kecerobohan yang dilakukan oleh dalam menjawab soal diakui oleh siswa tersebut. Saat diwawancarai siswa tersebut mengaku tidak terlalu fokus dalam menjawab soal hingga jawaban yang ditulis oleh siswa salah.

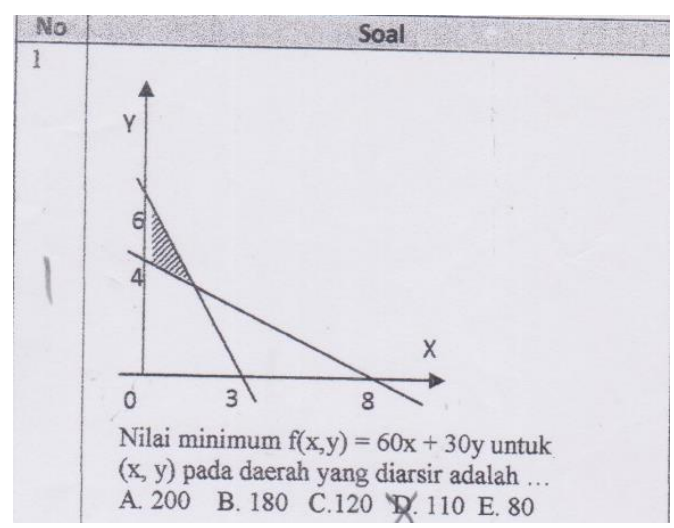

\section{Analisis Hasil Tes}

Peneliti menganalisis hasil jawaban. Analisis dilakukan untuk mengetahui letak kesalahan yang dilakukan siswa. Analisis dilakukan pada tiap soal yang telah diujikan 1. Analisis jawaban soal nomor 1

Berikut salah satu contoh hasil kerja siswa dalam menyelesaikan soal kemampuan matematis Nomor 1.

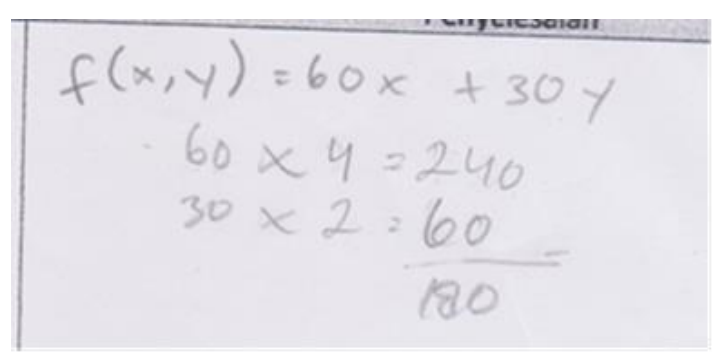

Gambar 4 Hasil Jawaban Siswa Nomor 1

Dalam gambar 1, siswa masih melakukan kesalahan dalam menghubungkan diagram terhadap ide smatematika. Siswa hanya menuliskan fungsi tujuan yang ada pada soal walaupun tetap ada kesalahan dalam menafsirkan cara menggunakan perhitungan terhadap fungsi tujuan.

Hal yang harus dilakukan oleh siswa adalah mencari titik potong dengan 
cara mengeliminasi dan mensubtitusi 2 buah persamaan garis yang ada pada grafik. Setelah mendapatkan titik tersebut siswa dapat mensubtitusikan titik potong tersebut dan titik-titik lainnya kepada fungsi tujuan.

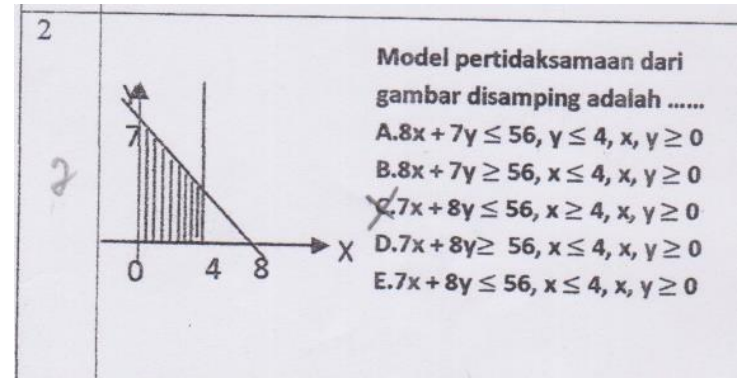

2. Analisis jawaban soal nomor 2

Berikut salah satu contoh hasil kerja siswa dalam menyelesaikan soal kemampuan matematis Nomor 2.

Gambar 5 Hasil Jawaban Soal Nomor 2

Berdasarkan gambar 2 siswa menuliskan 2 buah persamaan walaupun masih terdapat kesalahan dalam penulisannya, seperti menuliskan persamaan titik $\mathrm{x}$ dan $\mathrm{y}$ dalam grafik menjadi sebuah persamaan. Konsep yang digunakan haruslah siswa menuliskan titik $\mathrm{x}$ pada grafik menjadi titik $\mathrm{y}$ didalam persamaan begitupun titik y. Siswa pun masih melakukan kesalahan dalam menafsirkan arsiran pada grafik. Berdasarkan arsiran pada grafik, jelas bahwa arsiran tersebut berada pada bawah garis maka haruslah fungsi tersebut adalah $\leqslant$, tetapi siswa meuliskan $\geqslant$.

3. Analisis Jawaban Soal Nomor 3

Berikut salah satu contoh hasil kerja siswa dalam menyelesaikan soal kemampuan matematis Nomor 3.
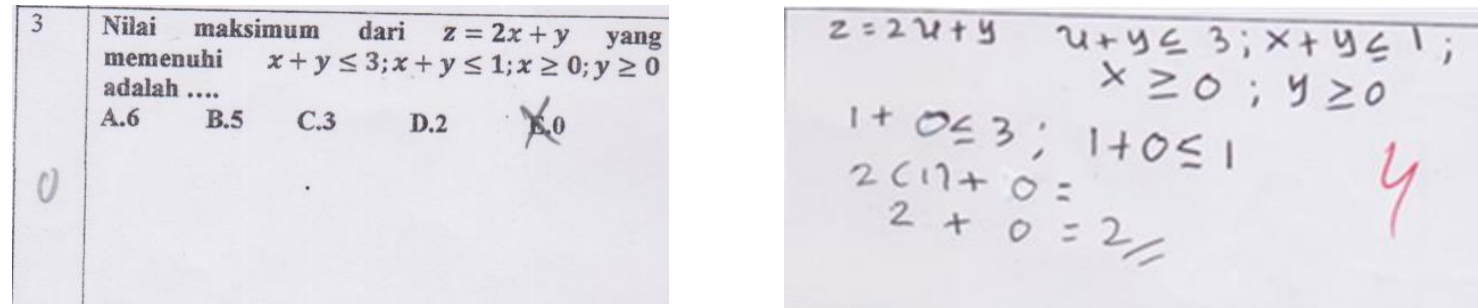

Gambar 6. Hasil Jawaban Soal Nomor 3

Dari gambar 3 dapat dilihat bahwa siswa masih melakukan kesalahan dalam menentukan titik-titik yang menjadi kemungkinan dalam menentukan sebuah nilai maksimum. Siswa hanya menuliskan kembali beberapa persamaan yang diketahui disoal kemudian mencoba melakukan perhitungan sesuai gambar 3 dan jelas itupun masih terdapat kesalahan. Haruslah siswa tersebut menentukan terlebih dahulu titik-titik yang menjadi kemamungkinan menjadikannya nilai maksminum, cara umum yang bisa digunakan adalah membuat sebuat grafik terlebih dahulu untuk mempermudah menentukan titik potong dan titik-titik 
lainnya. Kemudian siswa dapat menentukan hasil dari titik tersebut pada fungsi tujuan sehingga akan mendapatkan nilai yang diinginkan yaitu nilai maksimum.
4. Analisis Jawaban Soal Nomor 4

Berikut salah satu contoh hasil kerja siswa dalam menyelesaikan soal kemampuan matematis Nomor 4.
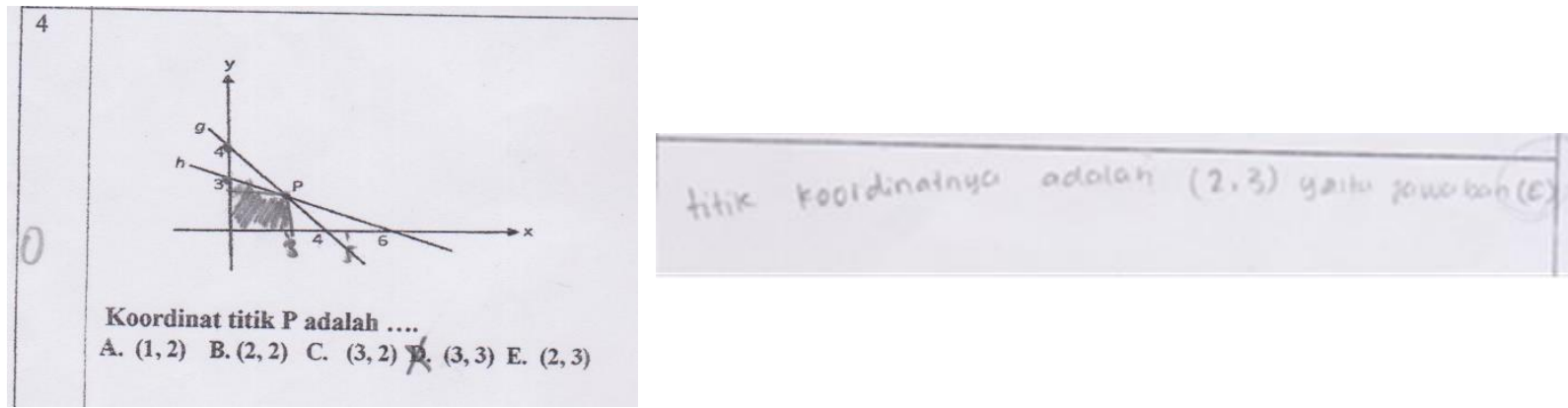

Gambar 7 Hasil Jawaban Siswa Nomor 4

Berdasarkan gambar 4 siswa tidak melakukan perhitungan. Dia hanya memprediksi kemungkinan titik $\mathrm{P}$ hanya berdasarkan gambar saja. Jelas hal ini salah. Selain jawabannya memang salah, peneliti menilai berdasarkan hasil uraian jawaban siswa tidak hanya berupa jawaban saja tanpa adanya proses perhitungan terlebih dahulu. Karena peneliti menilai berdasarkan proses siswa dalam mengerjakan soal tersebut.

Seharusnya siswa mencari titik potong dengan cara mengeliminasi dan mensubtitusi persamaan kedua garis yang ada pada grafik. Setelah mengeliminasi dan mensubtitusi persamaan garis tersebut, maka akan didapatkan sebuat nilai yang diinginkan, yaitu nilai dari titik P:

\section{Analisis Jawaban Soal Nomor 5 \\ Berikut salah satu contoh hasil kerja siswa dalam menyelesaikan soal kemampuan matematis Nomor 5.}

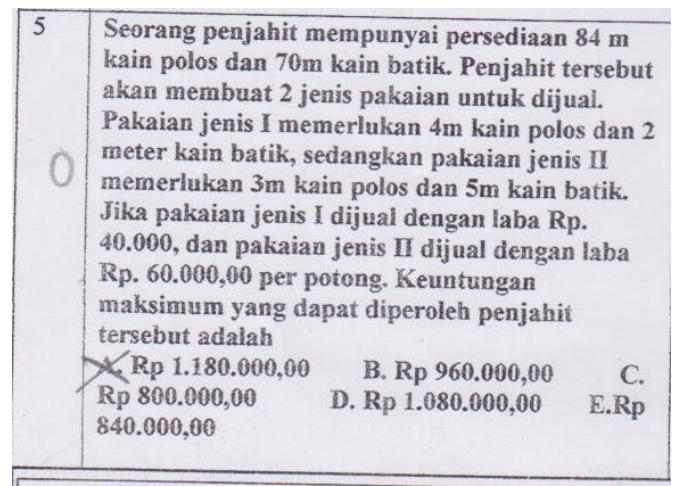

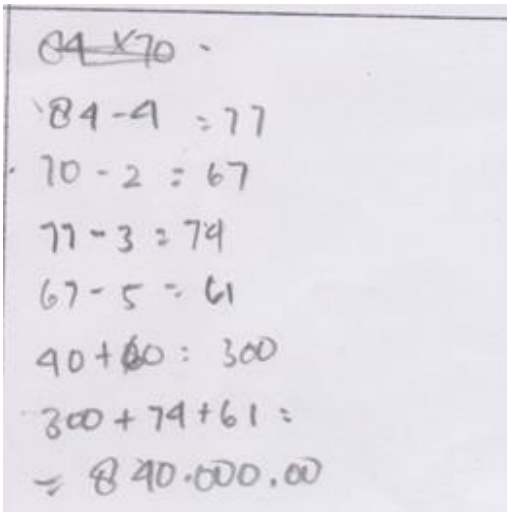

Tabel 7. Hasil Jawaban Soal Nomor 5 
Berdasarkan gambar 5 siswa tidak melakukan perhitungan dengan benar. Siswa tersebut hanya mengurangi beberapa angka dengan angka lainnya. Itupun bukanlah jawaban yang benar.

Dalam mengerjakan soal ini siswa seharusnya membuat tabel untuk menentukan sebuah persamaan. Setelah menentukan persamaan kemudian siswa tersebut dapat mencari sebuah titik dengan menjadikan salah satu titik dengan 0 sehingga mendapatkan beberapa tititk. Kemudian mengeliminasi dan mensubtitusi persamaan tersebut sehingga mendapatkan titik-titik untuk mencari nilai maksimun tersebut.

\section{Analisis Hasil Wawancara}

Wawancara dilakukan untuk mengetahui faktor-faktor siswa melakukan kesalahan. Selain untuk mengetahui faktorfaktor siswa melakukan kesalahan wawancara pun digunakan untuk memperkuat analisis yang dilakukan oleh peneliti. Beberapa faktor-faktor kesalahan yang dilakukan oleh siswa akan dideskripsikan sebagai berikut.

1. Lupa

Lupa menjadi penyebab yang sering dilakukan oleh siswa. Saat dilakukan wawancara untuk mengetahui penyebab siswa lupa karena siswa merasa bahwa ketika siswa dihadapkan dengan soal yang berbeda dengan contoh soal yang diberikan oleh guru siswa merasa kebingungan bahkan lupa harus mengerjakan soal tersebut (Rizkiani, Astri. Ari, 2019). Ada beberapa siswa yang bahkan lupa karena tidak belajar sebelumnya ketika dilakukan wawancara mengapa siswa tidak belajar siswa menjawab bahwa matematika merupakan mata pelajaran yang sulit dan rumit untuk dipelajari sehingga banyak siswa yang menghindari belajar matematika.

2. Kurang Teliti atau Ceroboh

Faktor selanjutnya adalah karena kurang teliti (Subekti, Untarti, \& Gunawan, 2016). Ketika siswa diwawancarai mengenai hal tersebut siswa menjawab karena siswa merasa waktu mengerjakan soal tersebut kurang sehingga siswa terburu-buru. Sehingga siswa kurang teliti dalam menjawab bahkan siswa tidak memiliki waktu untuk memeriksa kembali hasil jawabannya.

3. Kesulitan Belajar yang Dialami Siswa

Faktor lain adalah kesulitan belajar yang dialami siswa. Hal ini terjadi karena siswa masih tidak bisa mengikuti metode yang diterapkan oleh guru (Oktaviana, Syafrimen, \& Putra, 2018). Bahkan siswa pun tidak bisa mengimbangi kemampuan yang dimiliki oleh teman sebaya. Hal inipun yang menjadi penyebab siswa melakukan kesalahan. Saat ditanyai lebih lanjut penyebab siswa merasa kesulitan belajar adalah karena siswa merasa siswa memang tidak mengerti materi-materi sebelumnya yang menjadi materi prasyarat program linear. Hal ini jelas menjadi catatan penting bagi guru untuk mengevaluasi agar siswa dapat mengikuti pembelajaran dengan semestinya.

4. Waktu Belajar yang Kurang

Faktor terakhir penyebab siswa melakukan kesalahan dalam menjawab soal adalah karena waktu belajar yang kurang (Hanipa \& Sari, 2018).Hal ini disebabkan karena siswa memiliki waktu lebih banyak memainkan gadget daripada menbaca buku. Bahkan ada siswa yang mengaku lebih banyak bermain games dibandingkan dengan membaca atau mengulas materi yang sudah didapat. Mereka berpendapat bahwa lebih menyenangkan ketika 
menghabiskan waktu dengan gadget dari pada dengan buku pelajaran matematika (Kazimirov, 2018).

\section{SIMPULAN DAN SARAN}

\section{Simpulan}

1. Tingkat kemampuan komunikasi matematis siswa pada proses pembelajaran yang menggunakan pendekatan saintifik tergolong dalam kategori sedang dan rendah.

2. Bentuk kesalahan yang sering dilakukan siswa pada soal kemampuan komunikasi matematis diantaranya adalah kesalahan konsep, kesalahan prosedural yaitu dalam menggunakan Algoritma, dan kurang teliti atau ceroboh.

3. Penyebab siswa sering melakukan kesalahan pada soal kemampuan komunikasi matematis adalah lupa, kurang teliti, kesulitan belajar yang dialami siswa, waktu untuk belajar di rumah kurang.

\section{Saran}

Berdasarkan simpulan yang dibuat untuk menyelesaikan soal kemampuan komunikasi matematis pada materi program linear disarankan untuk melakukan tindakan-tindakan:

1. Alternatif pemecahan masalah pada jenis kesalahan kesalahan konsep adalah guru hendaknya mengetahui sejauh mana pemahaman konsep siswa terhadap materi yang diberikan.

2. Alternatif pemecahan masalah pada jenis kesalahan operasi hitung dan kurang teliti yaitu guru hendaknya menekankan siswa untuk teliti baik dalam operasi hitung, pengecekan jawaban dan teliti dalam mengerjakan soal.
3. Alternatif pemecahan masalah pada jenis kesalahan lupa, kurang teliti, kesulitan belajar yang dialami siswa, waktu untuk belajar di rumah kurang antara lain: guru memberikan motivasi kepada siswa agar lebih giat dalam belajar karena faktor penyebab kesalahan yang terjadi merupakan jenisjenis kesalahan internal yang dilakukan oleh siswa, guru dapat memberikan penjelesan yang mudah dimengerti dan dipahami oleh siswa agar siswa agar mudah memahami materi yang disajikan.

\section{DAFTAR PUSTAKA}

Anggriani, A., \& Septian, A. (2019). Peningkatan Kemampuan Komunikasi Matematis dan Kebiasaan Berpikir Siswa Melalui Model Pembelajaran IMPROVE. IndoMath: Indonesia Mathematics Education, 2(2), 105. https://doi.org/10.30738/indomath.v2i 2.4550

Hanipa, A., \& Sari, V. T. A. (2018). Analisis Kesalahan Siswa dalam Menyelesaikan Soal Sistem Persamaan Linear Dua Variabel pada Siswa kelas VIII MTs di Kabupaten Bandung Barat. Journal On Education, 1(2), 15-22.

Hendriana, H., \& Sumarmo, U. (2017). Penilaian Pembelajaran Matematika. In PT Refika Aditama.

Inayah, S., Septian, A., \& Suwarman, R. F. (2020). Student Procedural Fluency in Numerical Method Subjects. Desimal: Jurnal Matematika, 3(1), 53-64. https://doi.org/10.24042/djm.v3i1.531 6

Jusniani, N. (2018). Analisis Kesalahan Jawaban Siswa pada Kemampuan Pemahaman Matematis melalui Pembelajaran Kontekstual. PRISMA, 7(1), https://doi.org/10.35194/jp.v7i1.361

Kazimirov, A. N. (2018). Education at 
University and Industry 4.0. Proceedings - 2018 Global Smart Industry Conference, GloSIC 2018. https://doi.org/10.1109/GloSIC.2018.8 570076

KBBI. (2016). Kamus Besar Bahasa Indonesia ( KBBI ). Kementerian Pendidikan Dan Budaya, p. 4. Retrieved from http://kbbi.web.id/korpus

Kristofora, M., \& Sujadi, A. A. (2017). Analisis Kesalahan dalam Menyelesaikan Masalah Matematika dengan Menggunakan Langkah Poyla Siswa Kelas VII SMP. PRISMA, 6(1), 9-16. https://doi.org/10.35194/jp.v6i1.24

Maskur, R., Sumarno, Rahmawati, Y., Pradana, K., Syazali, M., Septian, A., \& Palupi, E. K. (2020). The effectiveness of problem based learning and aptitude treatment interaction in improving mathematical creative thinking skills on curriculum 2013. European Journal of Educational Research, 9(1), 375-383. https://doi.org/10.12973/eu-jer.9.1.375

Mufida, M. (2015). Analisis Kemampuan Komunikasi Matematis Pada Model PBL dengan Pendekatan Saintifik Berdasarkan Gaya Belajar Siswa Kelas VIII (Doctoral dissertation, UNIVERSITAS NEGERI SEMARANG).

NCTM. (2000). Principles and Standards for School Mathematics. In School Science and Mathematics (Vol. 47). Retrieved from www.nctm.org

Nopiyani, D., Turmudi, T., \& Prabawanto, S. (2018). Penerapan Pembelajaran Matematika Realistik Berbantuan GeoGebra untuk Meningkatkan Kemampuan Komunikasi Matematis Siswa SMP. Mosharafa: Jurnal Pendidikan Matematika, 5(2), 45-52. https://doi.org/10.31980/mosharafa.v5 i2.259

Oktaviana, D. V., Syafrimen, S., \& Putra, R. W. Y. (2018). Analisis Kemampuan Pemecahan Masalah Matematis Siswa Kelas IX MTS dalam Menyelesaikan Soal Model PISA pada Konten Perubahan Dan Hubungan. JES-MAT (Jurnal Edukasi Dan Sains Matematika), 4(1), 47. https://doi.org/10.25134/jesmat.v4i1.9 09

Permata, C. P., Kartono, K., \& Sunarmi, S. (2015). Analisis Kemampuan Komunikasi Matematis Siswa Kelas VIII SMP pada Model Pembelajaran TSTS dengan Pendekatan Scientific. Unnes Journal of Mathematics Education, 4(2).

Putra, J. D. (2017). Learning Cycle 5E Dalam Meningkatkan Kemampuan Komunikasi Matematis Dan SelfRegulated Learning Matematika. Prisma, 6(1), 43-56. https://doi.org/10.35194/jp.v6i1.27

Ramellan, P., Musdi, E., \& Armiati. (2012). Kemampuan Komunikasi Matematis Dan Pembelajaran Interaktif. Jurnal Pendidikan Matematika, Part, 1(2), 77-82.

Rizkiani, Astri. Ari, S. (2019). Kemampuan Metakognitif Siswa SMP dalam Pembelajaran Matematika dengan Menggunakan Pendekatan Realistic Mathematics Education ( RME ). UNION: Jurnal Pendidikan Matematika, 7(2), 275-284.

Schleicher, A. (2018). PISA 2018 insights and interpretations. In $O E C D$ Publishing. Retrieved from https://www.oecd.org/pisa/PISA 2018 Insights and Interpretations FINAL PDF.pdf

Subekti, F. E., Untarti, R., \& Gunawan, G. (2016). Identifikasi Kesalahan Jawaban Mahasiswa Ditinjau Dari Kemampuan Komunikasi Matematis. JES-MAT (Jurnal Edukasi Dan Sains Matematika), https://doi.org/10.25134/jesmat.v2i2.3 46

Sufairoh. (2016). Pendekatan Saintifik dan Model Pembelajaran K-13. Bahastra, 5(1), 89. https://doi.org/10.26555/bahastra.v37i 


\subsection{1}

Sugiyono. (2010). Metode Penelitian

Pendidikan Pendekatan Kuantitatif, kualitatif, dan $R \& D$. Bandung: Alfabeta.

Sun, Z., Xie, K., \& Anderman, L. H. (2018). The role of self-regulated learning in students' success in flipped undergraduate math courses. The Internet and Higher Education, 36, 41-53.

Wulandari, W. S. (2016). Meningkatkan Kemampuan Komunikasi dan Motivasi Belajar Matematika Siswa Sekolah Dasar Melalui Pembelajaran Kooperatif Tipe Think-Pair-Share. EduHumaniora | Jurnal Pendidikan Dasar Kampus Cibiru, 7(2), 198. https://doi.org/10.17509/eh.v7i2.2710 
